Младен Ухлик, Андрея Желе

Философский факультет Люблянского университета

\title{
Семантические и синтаксические особенности глаголов bati se 'бояться' и upati (se/si) 'надеяться; отваживаться' в словенском предложении
}

В статье делается попытка проанализировать синтаксические и семантические свойства глаголов bati se 'бояться', upati 'надеяться' и upati se/si 'отваживаться' с точки зрения их возможных дополнений, прежде всего выраженных придаточными изъяснительными и инфинитивами. Предполагается выявить также семантические и синтаксические условия, определяемые сочетаемостью и модальностью данных глаголов. Попытаемся дать ответ на вопрос, как на выбор наклонения в предложении с упомянутыми глаголами влияет взаимоотношения предиката в главном предложении и содержания дополнения.

Prispevek skuša predstaviti skladenjske in pomenske lastnosti glagolov bati se in upati (se/si) z vidika njunih zmožnosti predmetnih dopolnil - zlasti stavčnih in nedoločniških. Nameravamo predstaviti tudi pomenske in skladenjske pogoje, ki jih usmerja vezljivost in naklonskost omenjenih glagolov. Poskusili bomo odgovoriti, kako na izbiro naklona v povedi z omenjenima glagoloma vpliva soodnos med matičnim povedkom in vsebino dopolnila.

\section{1 Введение}

В статье делается попытка описать синтаксические и семантические свойства глаголов bati se 'бояться' и upati (se/si) ‘надеяться;отваживаться' с точки зрения их возможных дополнений - прежде всего, выраженных придаточными изъяснительными и инфинитивами. ${ }^{1}$

Объектные придаточные предложения, несомненно, относятся к дополнениям. В силу этого их семантика наиболее полно раскрывает содержание предиката главного предложения, что указывает на тесную связь или взаимовлияние двух предикатов - один из которых выступает в главном предложении, другой - в придаточном.

${ }^{1}$ Мы бы хотели поблагодарить М. Бенича, Е. Ю. Иванову, Е. М. Коницкую, Д. Крвину, М. В. Ослона и М. Н. Саенко за замечания и предложения по улучшению этой статьи. Ответственность за ошибки в интерпретациях и в анализе лежит только на авторах. 
В настоящей статье мы предполагаем представить семантические и синтаксические условия, определяемые сочетаемостью и модальностью глаголов bati se и upati (si/se). ${ }^{2}$

Их основные семантико-синтаксические особенности обусловлены возможностью или невозможностью присоединять инфинитивное дополнение.

Придаточные изъяснительные являются обязательными сентенциальными актантами, т. е. обязательными дополнениями, в основном, глаголов говорения и мышления в главном предложении, которые реализуют свои правые (объектные) актанты преимущественно придаточными изъяснительными. Благодаря высокой информативной значимости объектные придаточные приобретают высокую коммуникативную роль (Ďurovič 1959: 162).

В славянских языках в сложных предложениях с придаточными изъяснительными выбор союза часто обусловлен значением сказуемого в главном предложении.

(1) рус. Я бы хотел, чтобы мы еще раз встретились.

слов. Rad bi, da se še enkrat srečava ${ }_{(\mathrm{IND})}$. / Rad bi, da bi se še enkrat srečala ${ }_{(\mathrm{COND})}{ }^{3}$

(2) рус. Я знаю, что мы встретимся.

слов. Vem, da se bova srečala.

В словенском языке при глаголах говорения, мышления изъяснительно-объектные придаточное чаще всего вводится союзом $d a$ :

(3) слов. Ve, da je (IND) to nemogoče.

рус. Он знает, что это невозможно.

(4) слов. Pravi, da je to nemogoče.

рус. Он говорит, что это невозможно.

${ }^{2}$ Авторы придерживаются мнения, что между upati si и upati se в современном литературном словенском языке нет семантических различий. Преимущественное использование морфемы se или si зависит от особенностей конкретного словенского диалекта. Возможность вариативного использования $s e$ и $s i$ возникла благодаря их семантической опустошенности: в данном случае у морфем si и se нет собственно возвратного значения.

${ }^{3} \mathrm{~B}$ словенском варианты с наст. вр. индикатива (da se srečava) и сослагательным наклонением (da bi se srečala) имеют очень близкое значение. Если предложение выражает вежливую просьбу, чаще используется сослагательное наклонение. 
Выбор наклонения в подчиненном предложении в словенском языке зависит от выбранного глагольного значения в главном предложении, а часто также от отношения говорящего к содержанию и, как будет показано дальше, от его эмоциональной оценки содержания.

(5) слов. Ve, da bi bilo (COND) to nemogoče. ( $d a+$ сослагательное наклонение, выражающее ирреальность)

рус. Он знает, что это было бы невозможно.

(6) слов. Rekel je, (da) naj naredimo ${ }_{\text {(IND) }}$ vse, kar je mogoče. (союз (da) naj характерен для дополнений при глаголах манипуляции)

рус. Он сказал, чтобы мы сделали все возможное.

Сложные предложения с изъяснительно-объектными придаточными и главным предложением с глаголами bati se и upati свидетельствуют о взаимном семантическом отношении между главным и придаточным предложениями. Попытаемся ответить на вопрос, как на выбор наклонения предикатов сложного предложения влияют взаимоотношения между сказуемым в главном предложении и содержанием придаточного предложения.

\section{2. О многофункциональном союзе $d a$ (что)}

Для западно-южнославянских языков характерно очень широкое использование союза $d a$ (что), который может вводить разные типы придаточных предложений и который позиционно используется в начале зависимого предложения. ${ }^{4} \mathrm{~B}$ словенском языке союз $d a$ предсказывает актантную роль. В придаточном предложении за ним всегда следует личная форма глагола.

В этих случаях это значит также, что в словенском возможность использования инфинитива в роли объектного актанта очень ограничена.

\footnotetext{
${ }^{4}$ Использование словенского союза $d a$ (что) позиционно отличается, например, от болгарских предложений с союзом $\partial a$ (что). В большинстве болгарских предложений с составными союзами (макар $\partial a$, да не би $\partial а$ ) происходит разделение первой части (макар, да не би) и собственно союза да, который всегда стоит непосредственно перед предикатом. Между первой частью и собственно союзом $\partial a$ в болгарском языке ставятся клитики, отрицательные частицы, логическое подлежащее, акцентируемые дополнения и частицы (Иванова, Градинарова 2015: 253, 254). В словенском (так же, как и в хорватском и сербском) обязательность контактности $\partial a$ с глаголом отсутствует.
} 
(7) слов. Bilo je mrzlo, da se je ves tresel. (предложение с союзом $d a$ вводит обстоятельственное придаточное следствия $)^{5}$

рус. Было холодно, так что он весь дрожал.

(8) слов. Poklical ga je, da bi mu povedal dobro novico./ Da bi mu povedal dobro novico, ga je poklical. (предложение с союзом $d a$ вводит обстоятельственное придаточное цели)

рус. Он позвонил ему, чтобы рассказать хорошую новость.

(9) слов. (Тo,) da [...] / Da ga ne posluša, ni samo grdo, ampak preprosto ni prav. (предложение с союзом $d a$ вводит изъяснительно-субъектное, т. е. подлежащное придаточное)

рус. То, что он его не слушает, не только плохо, но и просто неправильно. (10) слов. Vsi so vedeli, da ga ne bo več nazaj. (предложение с союзом $d a$ вводит изъяснительно-объектное придаточное)

рус. Все знали, что он уже не вернется.

Следует упомянуть интересное различие подлежащных и объектных придаточных, связанное с актуальным членением предложения. Подлежащные придаточные изъяснительные в словенском языке часто выполняют отправную роль $($ mемыl) в сложном предложении: это значит, что и актуальное членение подчиняется основному предикативному отношению (SVO). Как показывает пример (9), подлежащные придаточные с союзом $d a$ (что) могут использоваться в начальной позиции даже без относительного местоимения to $(m o)$, в отличие от русского языка, где такое употребление имеет значительные ограничения.

Если подлежащное придаточное находится в позиции темы, использование союза da обязательно:

(11) *Ga ne posluša, ni samo grdo, ampak preprosto ni prav.

(12) *Preprosto ni prav, ga ne posluša.

Объектные придаточные соответствуют типичному актуальному членению занимают место и наполнение ремы. В случае с объектными придаточными переход прямой речи в придаточную клаузу сложноподчиненного предложения оформляется союзом $d a$, который, в отличие от подлежащного придаточного, может опускаться:

${ }^{5} \mathrm{O}$ том, что речь идет о придаточном со значением следствия, свидетельствует то, что $d a$ можно заменить союзом zato (рус. поэтому). 
(13) слов. Vsi so mislili, da ga ne bo več nazaj. $\leftarrow *$ Vsi so mislili, ga ne bo več nazaj $\leftarrow$ Vsi so mislili: ne bo ga več nazaj. ${ }^{6}$

рус. Все думали, что он уже не вернется. $\leftarrow$ Все думали: он уже не вернется.

По поводу специфики использования союза $d a$ в словенских объектных придаточных, следует подчеркнуть, что, в отличие от других славянских языков (например, русского, чешского и болгарского), в словенском нет особого союза, который бы вводил придаточные при предикатах желания или повеления. В русском, чешском и болгарском оппозиция между фактивностью и нефактивностью вводимой предикации обычно выражается оппозицией союзов (рус. что, чеш. že, болг. че - фактивность vs. pус. чтобы, чеш. $a b y$, болг. $\partial a$ - нефактивность при предикатах желания и повеления).

Так, при предикатах желания в словенском используется союз $d a$ как в изъявительном, так и в сослагательном наклонениях, в то время как в русском и чешском необходимо использовать особый союз с инфинитивом или формой сослагательного наклонения.

(14) слов. Želim si, da ti vse uspe ${ }_{\text {(IND) }}$ pravočasno narediti./ Želim si, da bi ti vse uspelo $_{(\mathrm{COND})}$ pravočasno narediti. ${ }^{7}$

рус. Желаю, чтобы тебе удалось всё сделать вовремя.

чеш. Přeji ti, abys všechno stihl udělat včas.

\section{3 Семантико-синтаксические особенности глаголов bati se и upati}

Рассматриваемые глаголы, в отличие от модальных želeti 'желать', hoteti 'хотеть', всегда полнозначны. Оба относятся к той группе глаголов, которые чаще всего присоединяют изъяснительно-объектные придаточные.

Прежде чем перейти к анализу случаев употребления с объектными придаточными, следует отметить некоторые семантические и категориальные особенности упомянутых глаголов, прежде всего в отношении использования категории вида, а также в сочетаемости и модальности.

Оба глагола тесно связаны с областью «субъективной модальности» (Падучева 2016) и выражают страх или надежду говорящего, который может в

${ }^{6}$ Приведенный пример различия места личного местоимения в объектном придаточном и прямой речи свидетельствует о пересечении закрепленного порядка следования клитик с актуальным членением.

${ }^{7}$ В похожих примерах действие, выраженное индикативом настоящего времени или сослагательным наклонением в придаточном предложении, имеет ирреальное значение и означает желание, чтобы ситуация возникла после момента речи. 
предложении выступать подлежащим, или его отношение к изъяснению, выраженному чаще всего объектным придаточным, но это может быть и дополнение в простом предложении.

Дополнение или изъяснительно-объектное придаточное при этих глаголах раскрывает суть желания субъекта в предложении, но как раз в выражении желания глаголы семантически противоположны; если при глаголе upati объектное придаточное вводит информацию о том, чего говорящий или субъект ожидает, то при глаголе bati se содержание объектного придаточного описывает ситуацию, которая, с точки зрения субъекта, является нежелательна: ${ }^{8}$

(15) слов. Upam, da bom prišel pravočasno. (Желание $+=$ Želim si, da bi prišel pravočasno.)

рус. Надеюсь, что приду вовремя. (Желание $+=$ Я хочу прийти вовремя) (16) слов. Војіm se, da ne bi zamudil. (Желание -=Želim si, da ne bi zamudil.)

рус. Боюсь, как бы не опоздать. (Желание - = Я хочу не опоздать)

Значение глагола bati se как раз из-за его ингерентной 'отрицательности' можно разложить на 'желать/надеяться, что что-то не произойдет', а с глаголом upati это невозможно; в то же время этот факт подтверждает, что глагол bati se семантически шире, чем upati. Последний входит в круг значений глагола bati se, при этом обратное невозможно.

По этой причине, как будет показано ниже, при глаголе bati se возможно факультативное плеонастическое отрицание (см. часть 5).

В то время как исходное значение глагола upati - 'надеяться на что-либо, рассчитывать на что-либо, ожидать чего-либо', возвратный глагол upati se/si имеет совершенно другое значение. Этот глагол не выражает субъективное желание субъекта, а скорее выступает в роли модального глагола типа smeti, которую в словенском языке можно продемонстрировать на следующих подзначениях: 9

// говорящий оценивает, имеется ли у субъекта предложения достаточно смелости и готовности сделать что-то необычное, непривычное:

(17) слов. Predstavljaj si, moj dedek si upa preplavati zaliv.

рус. Представь себе, мой дедушка настолько смелый, что может переплыть залив.

${ }^{8}$ Таким образом, словенский глагол bati se относится к группе глаголов опасения с апрехенсивным значением, которые «выражают опасение говорящего по поводу возможности наступления нежелательной, с его точки зрения, ситуации» (Плунгян 2004: 17). О синтаксических особенностях придаточных при глаголе bati se писал Г. Илц, отнесший этот глагол к «глаголам отрицания» (cp. Ilc 2012).

${ }^{9}$ Слов. глагол upati si является, по-видимому, калькой с немецкого sich trauen, при этом внутренняя форма обоих глаголов - «доверять себе» (М. Сной, личное сообщение). 
// говорящий может также проверять, готов и способен ли субъект предложения сделать что-то необычное:

(18) слов. Ali si upaš skočiti v mrzlo vodo?

рус. Ты рискнешь прыгнуть в холодную воду?

// говорящий выражает негативное отношение к субъекту предложения, который нарушил какую-то установленную норму:

(19) слов. Moj sosed si upa ozmerjati vsakega mimoidočega (говорящим это оценивается как нарушение нормы).

рус. Моему соседу хватает наглости наорать на любого прохожего (Мой сосед осмеливается наорать на любого прохожего).

Семантическое различие глаголов upati 'надеяться' и upati si/se 'отваживаться, осмеливаться' выражается и на синтаксическом уровне. Upati 'надеяться', как правило, сочетается с изъяснительно-объектными придаточными, а upati si/se 'отваживаться, осмеливаться', обычно - с инфинитивом в роли дополнения:

(20) слов. Upam, da bova pravočasno prispela na letališče.

рус. Я надеюсь, что мы вовремя доберёмся до аэропорта.

(21) слов. Upa si/se objavljati neresnice.

рус. Ему хвататает наглости публиковать откровенную ложь.

Upati si/se вступает в антонимические отношения с глаголом bati se с инфинитивом.

(22) слов. Bоji se začeti pogovor.= Ne upa si začeti pogovora.

рус. Он боится начать разговор. = Он не осмеливается начать разговор.

(23) слов. Upa si kršiti zakon = Ne boji se kršiti zakona.

рус. Он осмеливается нарушать закон $=$ Он не боится нарушать закон.

В некоторых примерах значение стативного глагола bati se можно понять как близкое к совершенному виду, поскольку он обозначает внешнюю ограниченость состояния за короткий промежуток времени:

(24) слов. V tistem trenutku se je bal to povedati.

рус. В тот момент он боялся это сказать. 
У глаголов upati и upati si/se нет видовой пары, они относятся к группе одновидовых модальных глаголов несовершенного вида (imperfectiva tantum), ${ }^{10}$ видовая оппозиция которых постепенно вырождается в безвидовость.

upati (надеяться):

(25) слов. Ko ga je zagledal, je upal, da mu bo vrnil denar. (значение совершенного вида)

рус. Когда он его увидел, то понадеялся, что тот вернет ему деньги.

(26) слов. Začeli smo upati na boljše. Že dolgo upam na bolje. (типовые примеры значения несовершенного вида при фазовых глаголах или наречном сочетании žе dolgo (уже давно))

рус. Мы начали надеяться на лучшее. Уже давно надеюсь на лучшее.

upati si (осмеливаться):

(27) слов. Kar naprej si upa ugovarjati. (значение несовершенного вида при наречии, обозначающем повторяемость действия)

рус. У него хватает смелости постоянно возражать.

(28) слов. Od tu si je včeraj upal skočiti. (значение совершенного вида)

рус. Он вчера рискнул отсюда прыгнуть.

3.1 Переходность обоих глаголов дополнительно выражается предлогами. Глагол bati se выступает в двух вариантах: во-первых, в значении 'испытывать страх' непосредственно с объектом-каузатором в форме родительного падежа - bati se česa (бояться чего):

(29) слов. Bojim se smrti, mačk, nesreče.

рус. Я боюсь смерти, кошек, несчастного случая.

Во-вторых, в сочетании с винительным с предлогом bati se za koga/kaj (бояться за кого/что), и имеет более целевое значение 'беспокоиться о/за':

(30) слов. Воjim se za srečo otrok. = Skrbi me sreča otrok.

рус. $=$ Я боюсь за счастье (судьбу) детей = Меня волнует счастье (судьба) детей.

${ }^{10}$ Cp. (Toporišič 2004: 350) и (Žele 2011: 26), где эти глаголы, как имеющие модальное значение, как и morati (быть должен), тось (мочь), utegniti (ycnemь, смочь), smeti $($ сметь), рассматривались как абсолютно несовершенные и как следствие - безвидовые. 
Глагол upati (надеяться) в значении 'ожидать, желать' используется как переходный с объектом (по большей части неодушевленным) в винительном падеже с предлогом na kaj (на что) и функционирует как целевой:

(31) слов. Upam na boljše čase/ na pomoč/ na podporo.

рус. Я надеюсь на лучшие времена/ на помощь/ на поддержку.

У возвратного глагола upati si/se (осмеливаться) место объекта блокировано семантически пустой возвратной морфемой $s e / s i{ }^{11}$ Таким образом, глаголу upati si/se располагает лишь возможностью присоединения дополнения в форме инфинитива, он не может сочетаться с именными дополнениями или придаточными предложениями.

(32) слов. Upam si vprašati. (Осмелюсь спросить)

*Upam si vprašanje. (блокированное именное дополнение)

*Upam si, da bi vprašal.

\section{4. Дополнения в форме инфинитива}

Инфинитивные дополнения с точки зрения целостности сообщения являются промежуточной ступенью между дополнениями в форме придаточного и именными дополнениями.

a) Boji se, da bi/bo/je njena mačka padla. (Он/она боится, что ее кот упадет/ упал) = дополнение в форме придаточного с вариативным использованием личных глагольных форм, ${ }^{12}$ благодаря чему оно более конкретно и информативно;

b) Boji se pasti. (Он/она боится упасть) = инфинитивное дополнение, средний уровень абстрактности;

c) Boji se padca. (Он/она боится падения) (= Ima strah pred padcem (У него/ нее страх падения)). = именное дополнение с наиболее абстрактным обозначением действия, выраженным отглагольным существительным.

${ }^{11}$ Подобным примером является также глагол drzniti si/se (дерзнуть), в отличие, скажем, от глагола dovoliti si (позволить себе), у которого морфема si сохраняет местоименное значение (si значит sebi (ceбe)).

${ }^{12} \mathrm{O}$ семантических различиях за счет разных комбинаций наклонений и времен см. ниже в части о дополнениях в форме придаточных. 
Использование инфинитивного дополнения, как мы увидим в дальнейшем, зависит как от соотношения между двумя предикатами (коокуренции), так и от кореференции субъектов главного и подчиненного предложений (Grickat 2004: 83). Инфинитивные дополнения по сравнению с дополнениями в виде придаточных предложений раскрывают содержание дополнения гораздо более абстрактно. Сочетание глагола с инфинитивом демонстрирует отчетливое разделение грамматических свойств между главным предикатом (bati se, upati) и инфинитивным дополнением. Предикат в главном предложении является носителем категории времени и наклонения, а инфинитивное дополнение выражает вид и валентность.

Модальный компонент как глагола bati se, так и глагола upati se/si ярко проявляется в использовании с немодальными инфинитивами, которые лишь называют дополнительное изъяснение.

(33) слов. Novinar se boji vprašati politika.

рус. Журналист боится спросить политика.

(34) слов. Novinar si (ne) upa vprašati politika.

рус. Журналист (не) осмеливается спросить политика.

В обоих примерах употребления инфинитивного дополнения проявляется необходимость кореферентности субъектов, т. е. экспериенцера - при предикатах страха в главном предложении, с субъектом действия, обозначенного инфинитивом. ${ }^{13}$

\section{1 Анализ bati se с дополнением в форме инфинитива}

Возникает вопрос, когда при одном и том же подлежащем может использоваться инфинитив, напр., Bojim se vprašati, Bojim se zaplavati. Смысловой выбор инфинитивов семантически диктует глагол bati se, изъяснение специфицирует инфинитив, объединяя сообщение в единое целое.

Посмотрим, как инфинитив конкретизирует содержание матричного предиката с помощью видового противопоставления. Словенский и русский материал языковых корпусов свидетельствует, что в обоих языках при глаголе bati se (бояться) чаще всего используются инфинитивы глаголов совершенного вида.

${ }^{13}$ Для сочетаний с инфинитивным дополнением в словенском языке это не всегда верно, напр., при глаголах восприятия: Slišal je ptičke peti (Oн слышал, как поют птич$\kappa u)$. Videl je ajdo cveteti (Он видел, как иветет гречиха). Следует упомянуть, что русским глагольным сочетаниям с глаголами лексико-семантической группы «посылать» (Его отправили купить газету) соответствуют словенские сочетания личной формы глагола и супина (Poslali so ga kupit časopis (Его послали купить газету). Dali so popravit uro (Они отдали часы в починку)). 
(35) слов. Воji se vstopiti/ vprašati/ pozdraviti.

рус. Он/она боится войти/ спросить/ поздороваться.

Во всех примерах инфинитив глаголов совершенного вида обозначает действие, которое следует за моментом речи.

В словенском языке при глаголе bati se реже используется инфинитив глаголов несовершенного вида, который выражает главным образом неактуальное настоящее время.

(36) слов. Војіm se stati na glavi/ voziti ponoči/ spraševati nadrejene.

рус. Я боюсь стоять на голове/ водить машину ночью/ спрашивать вышестоящих.

В противоположность сочетаниям глагола bati se с дополнением, выраженным придаточным, в славянских языках в глагольных сочетаниях с инфинитивом нельзя выразить действие, которое предшествовует моменту речи:

(37) слов. Bojim se, da sva izgubila potni list. $\neq$ Bojim se izgubiti potni list.

рус. Боюсь, что мы с тобой потеряли паспорт. $\neq$ Боюсь потерять паспорт.

\section{2 Анализ глагола upati si/se с дополнением в форме инфинитива}

В отличие от глагола upati, сочетания с инфинитивом в литературном словенском языке возможны только с возвратным глаголом upati si/se. ${ }^{14}$ И наоборот, русский глагол надеяться, эквивалент словенскому ираti, чаще сочетается с инфинитивом:

(38) рус. Он надеялся увидеть ее завтра. = слов. Upa, da jo bo jutri videl.

В роли инфинитивного дополнения могут выступать глаголы обоих видов.

(39) слов. Upam si govoriti o problemih. Upam si spregovoriti o problemih.

рус. У меня хватает смелости говорить о проблемах. У меня хватает смелости заговорить о проблемах.

Использование глагола upati без возвратных морфем в модальном значении 'мочь' представляет собой живое явление в отдельных юго-западных словенских диалектах, где этот глагол используется в значениях 1) ожидать (как и в литературном словенском) и 2) мочь (наряду с выражением ожидания, глагол получает значение возможности).

${ }^{14}$ Представляется, что в отношении невозвратного глагола upati ('ожидать') и возвратного upati si/se (ср. отношения между dovoliti и модальным dovoliti si, drzniti si/se) возвратность интенсифицирует субъектное отношение. 
(40) слов. диал. Danes ne upam priti. = лит. слов. Danes ne morem priti. (Сегодня я не могу прийти)

(41) слов. диал. Upam, da upaš priti. = лит. слов. Upam, da lahko prideš. (Я надеюсь, что ты сможешь прийти.)

Полисемия глагола upati в диалектах подтверждает также модальность всей семантики глагола upati, а также upati si/se.

В центральных словенских диалектах и в литературном словенском языке многозначный глагол upati с дополнениями в виде придаточных предложений используется в значение 'upati = pričakovati (ожидать)', в то время как использование при инфинитивном дополнении в значении 'upati = moči (мочь)' является диалектной особенностью.

\section{5 Дополнения в форме придаточного предложения}

Использование объектных придаточных при предикатах в главном предложении bati se и upati обеспечивает более независимую форму выражения изъяснения, что проявляется также в более независимом соотношении временных форм и наклонения. ${ }^{15}$ Если использование инфинитивного дополнения при упомянутых глаголах подразумевает обязательно общего субъекта, то дополнение в форме придаточного открывает возможность появления дополнительного субъекта в придаточном предложении.

(42) слов. Boji se vprašati. (субъект действия обязательно один и тот же).

рус. Он боится спросить.

(43) слов. Boji se, da ga bo soseda vprašala (субъект действия не один и тот же) рус. Он боится, что соседка его спросит.

С обоими глаголами могут использоваться все временные формы изъявительного наклонения, хотя материал корпуса текстов свидетельствует, что в словенском языке в индикативе чаще используются формы будущего времени. ${ }^{16}$

15 Эта семантическая и формальная независимость изъяснительно-объектного или подлежащного придаточного отражается также в том, что на него не влияет изменение диатезы в главном предложении, т. е. перехода из актива в пассив и обратно, напр., Bojim se, da ne bi vse popokalo (Боюсь, чтобы все не полопалось, потрескалось, повзрывалось) - Strah me je pred tem, da nе bi vse popokalo (Испьтываю страх, как бы все не полопалось, потрескалось, повзрывалось) (Ďurovič 1959: 164-165).

${ }^{16}$ Как показывают нижеприведенные схемы задания условий поиска в корпусе текстов при одном и другом глаголе преобладает использование форм будущего времени. Ситуация для глагола bati se такова: 
(44) слов. Politik se boji, da so volilci izvolili nasprotnika./ da (radi) volijo nasprotnika./ da bodo izvolili nasprotnika.

рус. Политик боится, что избиратели выбрали противника./ что избиратели с бо́льшим удовольствием голосуют за противника. / что выберут противника.

(45) слов. Politik upa, da volilci niso izvolili nasprotnika./ da ne volijo nasprotnika./ da ne bodo izvolili nasprotnika.

рус. Политик надеется, что избиратели не выбрали противника./ что не выбирают противника./ что не выберут противника.

\section{1 Анализ глагола bati se с дополнением в форме придаточного предложения}

Глагол bati se в словенском языке относится к глаголам, которые вводят объектные придаточные в изъявительном и условном наклонении, при этом выбор наклонения может влиять на интерпретацию предиката в главном предложении. Первичное значение этого глагола - выражение страха/беспокойства относительно ситуации, описываемой объектным придаточным.

Если в объектном придаточном используется индикатив в любой временной форме (чаще всего будущего времени), говорящий/субъект в предложении выражает обеспокоенность по поводу события, которое он считает вероятным:

(46) слов. Kakšna suša, bojim se, da ne bo dolgo deževalo.

рус. Какая засуха, боюсь, что долго не будет дождя.

Если комбинация глагола bati se и дополнения в форме придаточного с глаголом в будущем времени может выражать предсказание события, то это изъяснение нельзя без потери смысла заменить сочетанием bati se с инфинитивным дополнением.

[lemma="bati"][word="se"][word=","][word="da"][word="bom|boš|bo|bova|bosta|bom o|boste|bodo"] = 2393 найденных вхождения; [lemma="bati"][word="se"][word=","] [word="da"][word="sem|si|je|sva|sta|smo|ste|so"] $\{0,4\}[$ tag="Ggdd.*"] = 73 вхождения; [lemma="bati"][word="se"][word=","][word="da"] $\{0,4\}[$ tag="G.ds.*"] 7 найденных вхождений. Ситуация для глагола upati такова:

[lemma="upati"][word=","][word="da"][word="bom|boš|bo|bova|bosta|bomo|boste|bodo"] = 69077 найденных вхождений;

[lemma="upati"][word=","][word="da" $]\{0,2\}[$ tag="Gg.s. *" $]=\mathbf{3 , 1 3 4}$ найденных вхождения; [lemma="upati"][word=","][word="da"][tag="Gp-sp. *"']\{0,2\}[tag="Gg.d.*”] = 426 найденных вхождений;

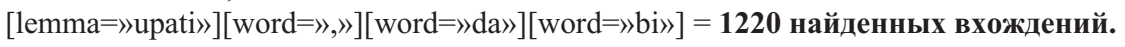


(47) слов. Bojim se, da bom izgubil stavo (акцент на предсказании вероятности). рус. Боюсь, я проиграю пари.

\# слов. Bojim se izgubiti stavo. (акцент на страхе).

рус. Боюсь проиграть пари.

(48) слов. Воjim se, da bodo rokometaši izgubili tekmo.

рус. Боюсь, гандболисты проиграют матч.

*Bojim se rokometaši izgubiti tekmo.

*Боюсь гандболистов проиграть матч.

Трансформация невозможна, поскольку вышеприведенное глагольное сочетание bati se izgubiti в предложении (48) объединяет два различных субъекта действия в роли подлежащих в предложении.

Если ситуация в объектном придаточном описывается сослагательным наклонением, то подчеркивается прежде всего желание говорящего, субъекта, чтобы ситуация не возникла, а не прогнозирование вероятности:

(49) слов. Bojim se, da (ne) bi pozabil denarnico. = Bojim se pozabiti denarnico.

рус. Боюсь, как бы я не забыл/как бы не забыть кошелек. = Боюсь забыть кошелек.

Если субъект, который одновременно является говорящим, желает, чтобы чего-то не произошло, в словенском языке это часто выражается сослагательным наклонением или будущим временем изъявительного наклонения. Такое употребление, характерное также для литературного языка, распространено в центрально-словенских регионах.

В сербском или хорватском в сентенциальных дополнениях с глаголом bojati se формы настоящего времени глаголов совершенного вида используются как главное средство для выражения страха (см. далее). Такое употребление настоящего времени в придаточном в словенском языке ограничивается говорами.

Глаголы совершенного вида в придаточных предложениях, где субъект не совпадает с субъектом главного предложения (напр.: Bojim se, da me avto ne povozi «Боюсь, чтобы меня не сбила машина»), в литературном словенском языке не употребляются в индикативе, по крайней мере, в материале корпуса текстов словенского языка такого не встречается.

Это существенный факт, поскольку в сербском, боснийском и хорватском предложения с глаголами совершенного вида в форме индикатива с отрицанием пе являются основным средством выражения страха и обеспокоенности: напр, с/х/б Bojim se da ne padnem/da se ne slomim/da se ne izgubim. (Боюсь, как бы не упасть/ не сломать себе чего/ не заблудиться).

Как было отмечено ранее, эту функцию в центральном словенском выполняет будущее время или сослагательное наклонение: 
(50) слов. Bojim se, da (ne) bom/ bi padel. Bojim se, da se ne bi/ bom polomil. Bojim se, da se ne bi/ bom izgubil.

рус. Боюсь, что упаду/ как бы не упасть. Боюсь, как бы не переломать себе чего/ что переломаю себе (напр., руки ноги). Боюсь, как бы не заблудиться / что заблужусь.

(51) хрв. Воjim se da ne padnem. ${ }^{17}$

слов. Bojim se, da (ne) bi padel. ${ }^{18}$

рус. Боюсь, как бы не упасть.

В словенском языке, реже чем в русском, в придаточном предложении встречается частица пе, не имеющая функции отрицания; ее употребление обусловлено ингерентным значением отрицания у глагола bati se. ${ }^{19}$

То, что в этих примерах мы имеем дело не семантическим отрицанием, подтверждают предложения со значимым использованием местоимений. Вместо отрицательных местоимений nihče (никто) и ničesar (ничего), характерных для двойного отрицания в придаточных, ${ }^{20}$ в примерах с плеонастическим отрицанием используются неопределенные местоимения kdo (кmo-нuбудь) и с̌еsa (чего-нибудь)/ kaj (что-нибудь) (разг.):

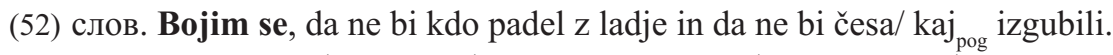

рус. Боюсь, как бы кто-нибудь не упал с корабля и чего-нибудь не потерял.

${ }^{17}$ В хорватском языке употребление будущего времени Bojim se da ću pasti обозначает не страх, а прогноз (Боюсь, уладу).

${ }^{18}$ Использование форм настоящего времени индикатива в придаточных предложениях, выражающих страх (а не прогноз), встречается главным образом в юго-западных словенских говорах, где вместо центрально-словенского Bojim se, da (ne) bi padla в некоторых говорах может использоваться Bojim se, da (ne) padem. В картотечном материале Института словенского языка Франа Рамовша мы нашли всего несколько примеров использования индикатива наст.вр. в придаточных при глаголе: Bojim se, da je ne zbudi moj duh (Боюсь, что ее не разбудит мой дух) (Отон Жупанчич); In tako se bojim, da se popolnoma nе pokvari. Я так боюсь, чтобы он/она полностью не испортился/испортилась (Иван Цанкар). Данные примеры встречаются у писателей первой половины XX века.

${ }^{19}$ Плеонастическое отрицание в придаточном при глаголе bati se можно толковать, как переход простого предложения с оптативным содержанием в сложное предложение: Samo da ne bi padel! (Только бы он не упал!) $\rightarrow$ Bojim se, da ne bi padel. (Боюсь, как бы он не упал).

${ }^{20}$ Если бы мы имели дело со смысловым отрицанием, то в словенском языке, требующем двойного отрицания, использовалось бы nihče (никто), напр. *Bojim se, da ne bi nihče padel z ladje (*Боюсь, что никто не упал бы с корабля). Об использовании плеонастического отрицания НЕ при глаголе бояться в русском языке см. (Brown, Franks 1995) и (Abbels 2005). 
В предложениях с сослагательным наклонением чаще, чем предложениях с индикативом, появляется плеонастическое отрицание, которое, как было отмечено, не является обязательным. ${ }^{21}$

(53) слов. Воjim se, da bi se v primeru nevarnosti zgodovina ponovila.

рус. Боюсь, как бы в случае опасности история не повторилась.

В русском языке связь отрицания глагола бояться более четко выражается как раз обязательным отрицанием дополнения в форме придаточного и инфинитива.

Сопоставление с материалом русского языка, приведенным Н. Р. Добрушиной (Добрушина 2016: 282), подтверждает, что ни в том, ни в другом языке сослагательное наклонение не может использоваться в придаточном предложении, если сказуемое придаточного предложения описывает событие или действие в прошлом:

(54) слов. Војіm se, da sem pred dvema urama pustila plin odprt.

рус. Боюсь, что два часа назад оставила газ открытым.

*Bojim se, da bi pred dvema urama pustila plin odprt.

*Боюсь, чтобы два часа назад оставила газ открытым.

Сослагательное наклонение как в словенском, так и в русском нейтрально по темпоральности, оно не может выражать временных отношений между главным и придаточным предложениями.

Еще одно различие русского и словенского языков в употреблении наклонения в придаточном предложении заключается в следующем.

Н. Р. Добрушина приходит к выводу, что в русском языке при отрицательном предикате бояться в придаточном предложении может использоваться только индикатив, а в словенском языке при отрицательном предикате в главном предложении, в придаточном преобладает форма сослагательного наклонения:

${ }^{21}$ О факультативности плеонастического отрицания писал также Й. Топоришич (Toporišič 2004: 395). В корпусе Gigafida найдено 108 примеров употребления конструкции Bojim se, da ne [...] (Боюсь, что не). Исключив повторы, получаем 80 реальных примеров. Преобладает сочетание с формами будущего времени (44 примера, или 55\%), где частица пе чаще всего выполняет функцию действительного отрицания. Помимо будущего времени в предложениях с Bojim se, da ne [...] используется также сослагательное наклонение (19 примеров) и настоящее время с глаголами несовершенного вида (misliti - думать, razumeti - nонимать, vedeti - знать) (17 примеров). В примерах с формами настоящего времени в придаточном предложении «bojim se» не выражает реального страха, а является вводным словом, демонстрирующим оценку говорящего. 
(55) слов. Ne bojim se, da bi ostala brez dela. рус. Не боюсь, что останусь без работы.

*Ne bojim se, da ostanem brez dela.

Материал корпуса текстов показывает, что в случае использования отрицательной формы глагола bati se в главном предложении в словенском языке возможны также примеры с одновременным отрицанием в придаточном предложении.

(56) слов. Ne bojim se, da ne bi uspeli organizirati koalicije v mestnem svetu.

рус. Не боюсь, что не успеют организовать коалицию в городском совете.

\section{2 Анализ употребления upati с дополнением в форме придаточного предложения}

В отличие от глагола bati se глагол upati в своем значении не содержит отрицания. Это значит, что любое использование отрицательной частицы в придаточном предложении обозначает действительное отрицание:

(57) слов. Upam, da ga ne bodo pretepli. = Upam, da ga bodo pretepli.

рус. Надеюсь, что его не побьют. $\neq$ Надеюсь, что его побьют.

Различие между изъявительным и сослагательным наклонением в дополнениях, выраженных придаточными предложениями, при глаголе bati se чаще всего связано с оппозицией прогноза вероятности (изъявительное) и желанием (сослагательное). При глаголе upati чаще всего встречается индикатив, сослагательное наклонение используется чаще, чем при русском глаголе надеяться, однако оно ограничено отдельными примерами контекста:

a) Сослагательное наклонение может значить, что утверждение (выражение желания или ожидания) выражено в предложении в мягкой форме.

(58) слов. Upam, da bi mi jutri pomagali. (более маркировано чем с изъявительным наклонением) // слов. Upam, da mi boste jutri pomagali.

рус. Надеюсь, что вы мне завтра сможете помочь.

б) Использование формы сослагательного наклонения при глаголе upati может означать также высокую степень ирреальности или маркированности действия как неосуществимого. 
(59) слов. Nekje v pustinjski Nevadi skladata črpalkar in učitelj klavirja popevčice ter neuspešno upata, da bi ju kdo odkril in odkupil njuno delo. ${ }^{22}$

рус. Где-то в пустыне Невада заправщик и учитель игры на фортепиано сочиняют песенки и безуспешно надеются, что о них кто-то узнает и купит их произведения.

\section{3 Стилистический аспект использования bati se и upati с дополнением в форме придаточного}

Когда речь идет о стилистическом использовании глаголов bati se и upati, прежде всего акцент делается на особом модальном употреблении. Для глагола bati se следует подчеркнуть употребление, которое смягчает содержание придаточного, а также в зависимости от контекста может иметь также иронический оттенок. Словарь словенского литературного языка (SSKJ) отмечает такие употребления как экспрессивы со значением 'domnevati (предполагать), misliti (думать), meniti (считать)'.

(60) слов. Bojim se, da boste izgubili stavo. Bojim se, da se motiš. Bojim se, da boš izgubil stavo.

рус. Боюсь, вы проиграете пари. Боюсь, ты ошибаешься. Боюсь, ты проиграешь пари.

Подобное использование глагола бояться в русском отмечает Н. Р. Добрушина, подчеркивая, что речь идет о сообщении информации, которая для адресата неприятна (Добрушина 2016: 282).

Случаи стилистического употребления с глаголом upati в главном предложении, в отличие от глагола bati se, окрашены более позитивно и порой звучат как извинение:

(61) слов. Upam, da vas ne motim.

рус. Надеюсь, я вас не отвлекаю.

Глагол upati в главном предложении может использоваться также как вежливое обращение, напр.:

(62) слов. Upam, da ne boste preveč hudi, če vas malo zmotim. Upam, da vas s pripovedovanjem ne nadlegujem.

рус. Надеюсь, Вы не очень рассердитесь, если я Вас немного побеспокою. Надеюсь, я Вам не надоедаю своим рассказом.

${ }^{22}$ Примеры из корпуса Gigafida [Электронный ресурс]. Дата обращения: 10. 2. 2017. 
В некоторых случаях с особой интонацией глагол upati с сентенциальным дополнением может выражать угрозу и предупреждение, напр.:

(63) слов. Upam, da si stvar premislil.

рус. Надеюсь, ты это обдумал.

или упрек:

(64) слов. Vi ste, upamo, to že preštudirali, saj imate knjigo že dolgo. ${ }^{23}$

рус. Вы, надеемся, это уже изучили, ведь книга у Вас уже долго.

\subsection{1 Использование bati se и upati в интерпозиции (оценочная модальность)}

Стилистическая особенность употребления заключается в том, что оба главных предиката - bati se и upati - могут использоваться также и в интерпозиции без союза $d a$. В этом случае они выражают не страх или ожидание, а субъективное отношение говорящего к сообщаемому содержанию.

(65) слов. Ko boste prebrali, boste, upam, razumeli.

рус. Когда вы прочитаете, вы, надеюсь, поймете.

(66) слов. Ko boste prebrali, boste, bojim se, prestrašeni.

рус. Когда вы прочитаете, вы, боюсь, испугаетесь.

В этих примерах ослабляется значение предшествования, выражаемого в придаточном предложении, при этом благодаря глаголам upati и bati se, смысловой акцент переносится на оценку, которую говорящий дает предикату в главном предложении.

\section{6 Заключение}

По сравнению с модальными глаголами желания и возможности, глаголы bati se 'бояться' и upati (si/se) 'надеяться; осмеливаться' семантически более сложны, поскольку каждый в своем значении объединяет 'желание, отрицание' (bati se - бояться), 'желание, ожидание' (ираti - надеяться) и 'возможность, оценку' (ираti si-осмеливаться, решиться).

Глаголы bati se (бояться) и upati (надеяться) в дополнениях или в придаточных предложениях допускают большой выбор видовременных форм и

${ }^{23}$ Подобные примеры с соответствующим квалификатором отмечает и Словарь словенского литературного языка. 
модальных оттенков. Так, например, они позволяют использовать индикатив совершенного вида прошедшего времени, что невозможно при глаголах, выражающих желание, ср.: Boji se / Upa, da so prodali stanovanje (Он боится) надеется, что квартиру продали) в противоположность *Želi/ Hoče/ Zahteva, da so prodali stanovanje (*Он хочет/mребует, что квартиру продали) и т. д.

В отличие от bati se и upati, у возвратного глагола upati si/se 'осмеливаться' место прямого дополнения блокирует возвратная морфема $s e / s i$, поэтому у него остается только возможность присоединения дополнения в форме инфинитива, напр.: Upa si vprašati (Он осмеливается спросить) в отличие от *Upa si, da bi vprašal (*Он осмеливается, чтобы спросить) / *Upa si vprašanje (*Oн осмеливается вопрос).

Мы показали, что дополнения в форме инфинитива с точки зрения информативности (информации о действии) являются промежуточной ступенью между дополнением в форме придаточного и именным дополнением. По сравнению с дополнениями в форме придаточного у инфинитивных дополнений более ярко выражается разделение грамматических свойств между предикатом в главном предложении (bati se, upati (si/se)) и инфинитивным дополнением. В сочетаниях с инфинитивом предикат в главном предложении является носителем времени и наклонения, а инфинитивные дополнения выражают вид и валентность.

Стилистически маркированное использование как глагола bati se, так и upati переносит акцент на оценочную модальность: Bojim se, da pa pri tem nimate prav (Боюсь, Вы в этом не правы) в значении 'Morda pa pri tem nimate prav' (Возможно, Вы в этом не правы).

Вышеупомянутые глаголы с отдельными рассмотренными семантикосинтаксическими особенностями представляют семантическую, синтаксическую и стилистическую связь между полнозначными глаголами говорения, мышления, чувствования, с одной стороны, и модальными глаголами, выражающими желание и возможность, с другой. Это подтверждается возможностью их полнозначного или полнозначно-модального употребления в сочетании с инфинитивом или дополнением в форме придаточного предложения.

Хотелось бы надеяться, что настоящая статья станет стимулом для дальнейших исследований их синтаксических свойств и особенностей, которые позволят осуществить более исчерпывающие словарные описания глаголов bati se, upati и upati si/se, а также семантически близких глаголов в словенском языке. Представляет интерес также сопоставление особенностей словенских модальных глаголов с их эквивалентами в других славянских языках. 


\section{Литература}

Abels, Klaus. 2005. 'Expletive Negation' in Russian: A Conspiracy Theory. Journal of Slavic linguistics 13/1: 5-74.

Brown, Sue. Franks, Steven. 1995. Asymmetries in the scope of Russian negation. Journal of Slavic Linguistics 3: 239-287.

Duurovič, Ludomír. 1959. Obsahové vedl'ajšie vety. Jazykovedné štúdie IV. Spisovný jazyk, 155167. Bratislava: Vydavatel'stvo Slovenskej akadémie vied.

Fran = Fran: slovarji Inštituta za slovenski jezik Frana Ramovša ZRC SAZU. www.fran.si, вход 28. 1. 2017).

GigaFida, korpusna besedilna zbirka, http://www.gigafida.net, вход 23. 1. 2016.

Ilc, Gašper. 2012. Skladenjska okolja pleonastičnega zanikanja. Slavistična revija 60/4: 674-675.

Inštitut za slovenski jezik Frana Ramovša ZRC SAZU. Skenirana listkovna kartoteka za razlagalni Slovar slovenskega knjižnega jezika. 1945-1986.

Karolak, Stanisław. 2001. Od semantyki do gramatyki. Wybór rozpraw. Warszawa: Instytucia Slawistyki PAN.

Noonan, Michael. 2007. Complementation. Language typology and syntactic description, vol. II: Complex constructions, 52-150. Cambridge: Cambridge University Press.

Svoboda, Karel. 1961. Parataxe a hypotaxe z hlediska modální výstavby souvětí. Slovo a slovesnost 22/4: 241-254.

Toporišič, Jože. 1992: Enciklopedija slovenskega jezika. Ljubljana: Cankarjeva založba.

Toporišič, Jože. 2000. Slovenska slovnica (SS). Četrta prenovljena in razširjena izdaja. Maribor: Obzorja.

Zorikhina-Nilsson, Nadezhda. 2012. Peculiarities of expressing the apprehensive in Russian.

Oslo Studies in Language 4/1: 53-70.

Andreja Žele, 2011. Leksemski in skladenjski vpliv na vidskost (na primeru slovenščine). Opera Slavica 21/4: 22-35.

Грицкат, Ирена. 2004 (1975). Ширење везника $\partial a$ у неиндикативним реченицама (замена инфинитива, вољних и намерних конструкција). Студије из историје српскохрватског језика, 83-111. Београд: Завод за уџбенике и наставна средства.

Добрушина, Нина Р. 2016. Сослагательное наклонение в русском языке. Опыт исследования грамматической семантики. Прага: Animedia Company.

Иванова, Елена Юрьевна. Градинарова, Алла Анатольевна. 2015. Синтаксическая система болгарского языка на фоне русского. Москва: Языки славянской культуры.

Падучева, Елена Викторовна. 2016. Модальность: Материальл для проекта корпусного описания русской грамматики. http://rusgram.ru/Модальность, вход 1. 2. 2017.

Плунгян, Владимир Александрович. 2004. Предисловие. In: Ландер, Юрий А., Плунгян Владимир А., Урманчиева, Анна Й. 2004. Исследования по теории грамматики: Ирреалис и ирреальность. Выпуск 3. Москва: Гнозис.

Prispelo marca 2017, sprejeto maja 2017.

Received March 2017, accepted May 2017. 


\section{Pomenske in skladenjske posebnosti glagolov bati se in upati (si/se) v slovenski povedi}

V primerjavi z naklonskimi glagoli izražanja želje in možnosti, sta bati se in upati ( $\mathrm{si} / \mathrm{se}$ ) pomensko kompleksnejša, ker vsak zase v svojem pomenju združujeta 'željo, zanikanje' (bati se), 'željo, pričakovanje' (upati) in 'možnost, oceno' (upati si).

Glagola bati se in upati v stavčnih dopolnilih oz. odvisnikih omogočata veliko izbiro časovnih in vidskih oblik ter odtenkov naklonskosti. Tako denimo dovoljujeta rabo dovršnega preteklika indikativa, kar pri glagolih, ki izražajo željo, ni mogoče, npr.: Boji se / Upa, da je odšel povedat nasproti *Želi/ Hočel Zahteva, da je odšel povedat ipd.

V nasprotju z bati se in upati pri povratnem glagolu upati si/se mesto predmeta blokira pomensko prazen morfem se/si, zato mu preostane samo še možnost nedoločniškega dopolnila, npr.: Upa si vprašati nasproti *Upa si, da bi vprašal / *Upa si vprašanje.

Na splošno pa se nedoločniška dopolnila glede na sporočilnost (informacijo o dejanju) potrjujejo kot vmesna stopnja med stavčnim in imenskim dopolnilom. V primerjavi s stavčnimi dopolnili pa se pri nedoločniških dopolnilih bolj eksplicitno izrazi razdelitev slovničnih lastnosti med matičnim povedkom (bati se, upati (si) se)) in nedoločniškim dopolnilom. V zvezah jedra z nedoločnikom je matični povedek nosilec časa in naklona, nedoločniško dopolnilo pa izraža vid in valenco.

Stilno zaznamovana raba tako bati se kot upati pri izhodiščno polnopomenskih glagolih prenese poudarek na vrednotenjsko modalnost: Bojim se, da pa pri tem nimate prav; Upam, da vas ne motim.

Vsekakor omenjena glagola z nekaterimi obravnavanimi pomensko-skladenjskimi lastnostmi predstavljata pomensko, skladenjsko in stilno povezavo med polnopomenskimi glagoli rekanja, mišljenja, čutenja na eni strani in modalnimi glagoli, ki izražajo željo in zmožnost na drugi strani. To lepo potrjuje tudi njihova zmožnost polnopomenske ali polnopomensko-modalne rabe $\mathrm{v}$ zvezi z nedoločniškim ali stavčnim dopolnilom.

Ta razprava naj bo hkrati tudi vzpodbuda za nadaljnje obravnave njihovih skladenjskih lastnosti in posebnosti, ki seveda posledično prinašajo tudi izčrpnejše slovarske predstavitve glagolov bati se, upati in upati si/se in prav tako njim sorodnih glagolov v slovenščini. Zanimiva pa je tudi s stališča primerjave posebnosti slovenskih modalnih glagolov z ustrezniki v drugih slovanskih jezikih. 


\section{Semantic and syntactic features of the verbs bati se 'to fear' and upati (si/se) 'to hope; to dare' in the Slovenian sentence}

Compared to the modal verbs of desire and possibility, the verbs bati se 'to fear', upati 'to hope', upati si/se 'to dare' are semantically more complex, since they combine the meanings of 'negative desire' (bati se - to fear), 'desire, expectation' (upati - to hope) and 'ability, evaluation' (upati si - to dare).

The verbs bati se (to fear) and upati (to hope) allow for a large selection of aspectual-temporal forms and modal shades in sentential complements (subordinate clauses). For instance, they can take a perfective verb in the past tense, which is impossible with verbs of desire, cf.: Boji se / Upa, da so prodali stanovanje (He is afraid / hopes that the apartment was sold) as opposed to *Želi / Hoče / Zahteva, da so prodali stanovanje ( ${ }^{*} \mathrm{He}$ wants / demands that the apartment was sold), etc.

Unlike bati se and upati, the reflexive verb upati si/se 'dare' cannot take a direct object since that valency is blocked by the reflexive morpheme se/si, hence, only infinitve complements are allowed, e.g.: Upa si vprašati (He dares to ask) in contrast to *Upa si, da bi vprašal (*He dares in order to ask) / *Upa si vprašanje (*He dares the question).

We have shown that, from the point of view of information value (information about the action), infinitive complements are half-way between sentential and nominal complements. Compared to sentence-like complements, infinitive complements allow for a clearer distinction between the grammatical properties of the matrix predicate (bati se, upati ( $\mathrm{si} / \mathrm{se}$ )) and those of the complement, expressed by the infinitive. In combinations with the infinitive, the matrix predicate displays the features of time and mood, while the infinitive expresses aspect and valency.

The stylistically marked use of both bati se and upati transfers the emphasis to epistemic modality: Bojim se, da pa pri tem nimate prav (I'm afraid you are wrong about this) in the sense of 'Morda pa pri tem nimate prav' (Perhaps you are not right about this).

The verbs in question along with some of their semantic and syntactic features outlined above represent a semantic, syntactic and stylistic link between the content verbs of speaking, thinking, feeling, on the one hand, and modal verbs expressing desire and ability, on the other. This is confirmed by their ability to be used as content verbs or semi-content modal-like verbs in combination with infinitive or sentential complements.

We hope that this article will stimulate further study of the syntactic properties and features of the verbs bati se, upati and upati si/se, which may, in turn, facilitate a better, more comprehensive lexical description of these, as well as of other, semantically similar, verbs in Slovenian. It will also be of interest to compare the peculiarities of Slovenian modal verbs with their equivalents in other Slavic languages. 